\title{
SISTEM KENDALI ARSIP KEPEGAWAIAN (SIKASEP) BERBASIS DESKTOP PADA BALAI SOSIAL BINA REMAJA (BSBR) KARYA MANDIRI
}

\author{
(Desktop Based Personnel Archive Control System At Balai Sosial Bina Remaja (BSBR) \\ Karya Mandiri)
}

\author{
Moh. Ali Albar*, Hidayatul Akbar \\ Program Studi Teknik Informatika, Fakultas Teknik, Universitas Mataram \\ JI. Majapahit 62, Mataram, Lombok NTB, INDONESIA \\ Email:mohalialbar@unram.ac.id, hidayatul.akbar96@gmail.com
}

\begin{abstract}
At present, BSBR Karya Mandiri implements staff filing to manage curriculum vitae, leave, transfer, salary, rank, pension, and rank order list (DUK). This is still done manually so that the data search process becomes very long. Therefore, BSBR Karya Mandiri requires a personnel archive information system. This application development methodology uses the SDLC method. This system aims to manage employee data easily, effectively and efficiently. This system is desktop based and uses the Java programming language. The results of this application use questionnaire show that as many as 24 respondents stated that they agreed to $80 \%$ and as many as 6 respondents stated that they strongly agreed to $20 \%$.
\end{abstract}

Keywords: Information system, SDLC, Desktop, Java

*Penulis korespondensi

\section{Pendahuluan}

Teknologi informasi sudah merambah ke dalam organisasi. Arsip berpengaruh besar terhadap organisasi. Oleh karena itu, pengelolaan arsip harus dilakukan secara baik dan benar, agar dapat membantu kinerja organisasi tersebut.

Pada saat ini, di Balai Sosial Bina Remaja (BSBR) "Karya Mandiri" prosedur yang diterapkan dalam hal pengarsipan kepegawaian seperti daftar riwayat hidup, cuti pegawai, kenaikan gaji dan pangkat, pensiun, DUK, hingga mutasi masih tradisional yaitu berupa penulisan atau pencatatan menggunakan buku. Penyimpanan data-data kepegawaian masih dilakukan secara konvensional sehingga ketika dilakukan pencarian dokumen-dokumen membutuhkan waktu lama dan kemungkinan datanya hilang.

Berdasarkan uraian tersebut, maka dibuatlah "Sistem Kendali Arsip Kepegawaian (SIKASEP) Berbasis Desktop pada Balai Sosial Bina Remaja (BSBR) "Karya Mandiri". Sistem informasi ini diharapkan dapat memudahkan dalam pencatatan arsip pegawai yang efektif, aman, cepat, dan efisien.

\section{Tinjauan Pustaka}

Sistem informasi arsip dan kepegawaian telah dilakukan dalam beberapa penelitian, penelitian tersebut menggunakan metode System Development
Life Cycle (SLDC) dalam pengembangannya. Metode SDLC dimulai dari tahap analisis sistem, tahap perancangan sistem, tahap implementasi sistem, tahap pengujian sistem, dan tahap pemeliharaan sistem, dan dilakukan dalam bentuk suatu siklus kerja [1][2][3][4][5][6][7][8][9][10]. Berdasarkan 10 penelitian yang membahas mengenai informasi arsip dan kepegawaian didapatkan beberapa kesimpulan. Fitur yang ditawarkan yaitu pengelolaan surat masuk dan keluar, surat perintah perjalanan dinas (SPPD), pengelolaan arsip. Sistem yang dibuat pada penelitian tersebut, ada yang berbasis web [1][2][3][5][6][7][8][9][10] dan desktop [4]. Selain itu, pengembangan sistemnya berorientasi objek [1][2][3][6][7] dan berorientasi non objek (struktural) [4][5][8][9][10]. Pada beberapa penelitian tersebut, untuk tahap kuesionernya tidak semua dilakukan, hanya beberapa penelitian yang melakukan kuesioner terhadap responden. Respon setuju dari hasil kuesioner yaitu $53,3 \%$ dan respon sangat setuju yaitu $46,7 \%$ terhadap sistem informasi kepegawaian yang dibuat. Keterbaruan dari penelitian ini sendiri untuk merancang dan membuat sistem informasi pengarsipan data pegawai yang aman dalam melakukan manajemen data kepegawaian, dapat diketemukan dengan mudah, cepat dan tepat yang terkomputerisasi dan berbasis desktop menggunakan 
bahasa pemrograman java dan berorientasi objek. Perancangan sistem kendali arsip kepegawaian menampilkan beberapa fitur yang belum dilakukan pada penelitian sebelumnya. Fitur tersebut antara lain mengelola daftar riwayat hidup, mengelola gaji, mengelola mutasi, mengelola pensiun, dan mengelola kepangkatan pegawai.

\section{Metode Penelitian}

Metodelogi pengembangan sistem ini menggunakan metode Systems Development Life Cycle (SDLC). Metode ini antara lain analisis, perancangan, implementasi, dan pengujian. Deskripsi sistem dan tahapan proses penelitian ini dapat di lihat pada poin di bawah ini.

\subsection{Analisis Sistem}

Alur kerja antara sistem lama dan sistem baru hasil rancangan sistem informasi arsip kepegawaian dapat dilihat perbedaannya sebagai berikut.

\subsubsection{Sistem Lama}

Prosedur pengarsipan data pegawai pada Balai Sosial Bina Remaja "Karya Mandiri" masih dilakukan secara manual. Data-data pegawai baik meliputi gaji, kenaikan pangkat, daftar cuti masih dilakukan dengan cara pembukuan. Cara ini tentunya masih kurang dalam segi keamanan data.

Pencarian dokumen-dokumen pegawai juga terbilang sukar dalam pencarian data lama dalam buku yang digunakan dan mencarinya satu persatu. Hal ini menyebabkan pencarian data menjadi lama dan tidak efisien.

Data yang tidak dicatat dalam buku dan berkas lainnya juga dapat menyebabkan ketidakjelasan dalam manajemen pengarsipan. Selain itu tidak adanya data rekaman untuk mengingatkan apabila seorang pegawai telah mendekati dan atau melewati masa cuti, kenaikan gaji, pangkat, pensiun dan sebagainya.

\subsubsection{Sistem Baru}

Sistem Kendali Arsip Kepegawaian (SIKASEP) pada Balai Sosial Bina Remaja "Karya Mandiri" dibuat untuk dapat mencoba memberikan solusi untuk permasalahan manajemen pengarsipan data pegawai yang masih dilakukan secara konvensional. Sistem ini hanya digunakan oleh operator sebagai inputer yang bertugas untuk mencatat segala bentuk data yang ada dari setiap pegawai.

\subsection{Perancangan Sistem}

Pada pembuatan sebuah sistem informasi ini dilakukan dalam beberapa tahap. Salah satunya adalah perancangan sistem. Perancangan sistem informasi bertujuan untuk menggambarkan suatu masalah supaya mudah untuk mendapatkan solusi dari masalah tersebut. Berikut adalah tahapan perancangan yang ada dalam sistem informasi arsip elektronik ini.

\subsubsection{Use Case Diagram}

Diagram ini pada aplikasi arsip elektronik ini bertujuan untuk menjelaskan aktifitas yang dapat dilakukan seorang user yang hendak menggunakan sistem atau dengan kata lain use case berfungsi menggambarkan aksi dari user dan sistem. User dari sistem informasi ini adalah hanya operator. Berikut use case diagram dari sistem informasi yang dibuat untuk pengguna sistem ditunjukan oleh Gambar 1.

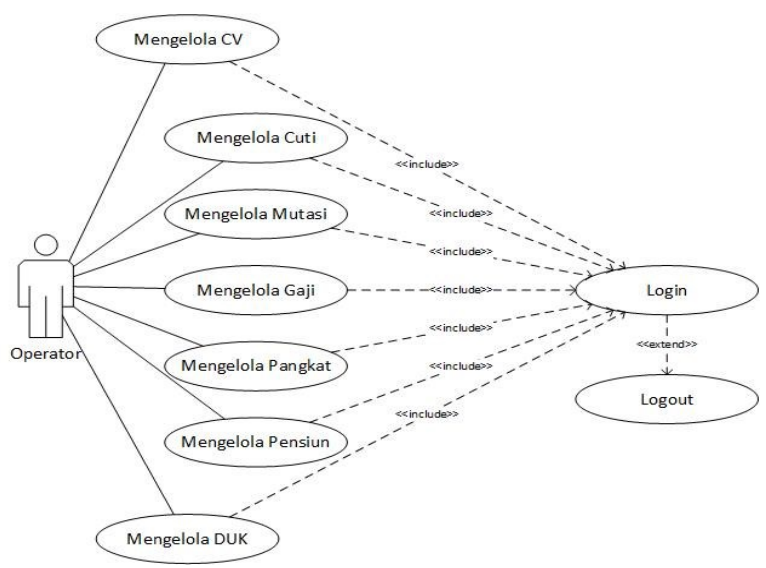

Gambar 1. Diagram Use Case SIKASEP

\subsubsection{Class Diagram}

Diagram ini memperlihatkan relasi setiap entitas pada aplikasi ini. Class diagram ini mengambarkan struktur dari entitas yang memiliki atribut dan method. Gambar 2 merupakan class diagram dari sistem ini.

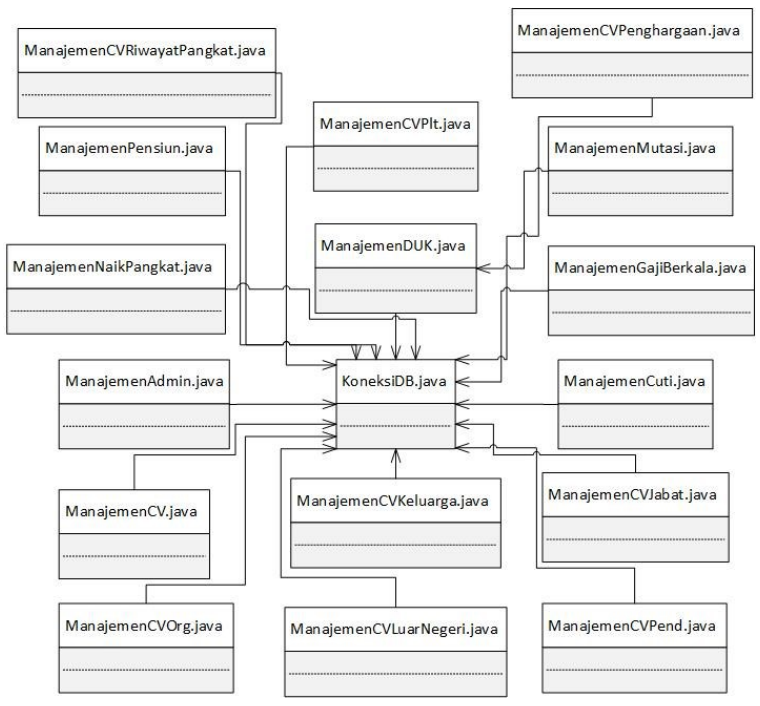




\section{Gambar 2. Diagram Class SIKASEP (Controller)}

\subsubsection{Sequence Diagram}

Berikut penjelasan Sequence Diagram dari sistem ini.

\subsubsection{Proses Login}

Pada Sequence Diagram ini menjelaskan bagaimana proses login dari aplikasi yang akan dijalankan. Pertama user berperan sebagai aktor yang akan mengakses halaman login dan memasukan username dan password. Kemudian program akan memeriksa apakah input sudah benar dari username dan password, jika benar maka program akan masuk ke halaman utama, sedangkan jika salah maka program akan menampilkan pesan yang menyatakan bahwa data yang dimasukan oleh user tidak tersedia. Sequence diagram dari proses login ditunjukan pada Gambar 3.

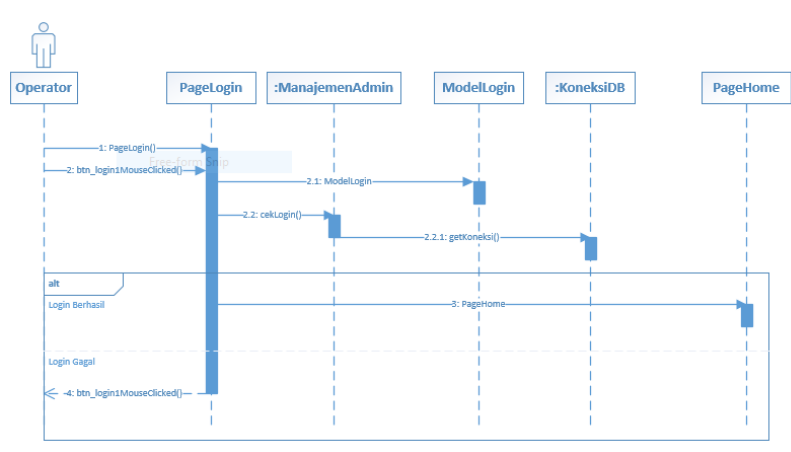

Gambar 3. Proses Login

\subsubsection{Proses Lihat Data}

Pada aplikasi ini user dapat melihat data-data yang tersedia. Gambar 4 menjelaskan proses lihat data jika user telah memilih menu pada menu utama kemudian program akan menampilkan data dari database dalam bentuk tabel ke halaman menu yang diakses tersebut.

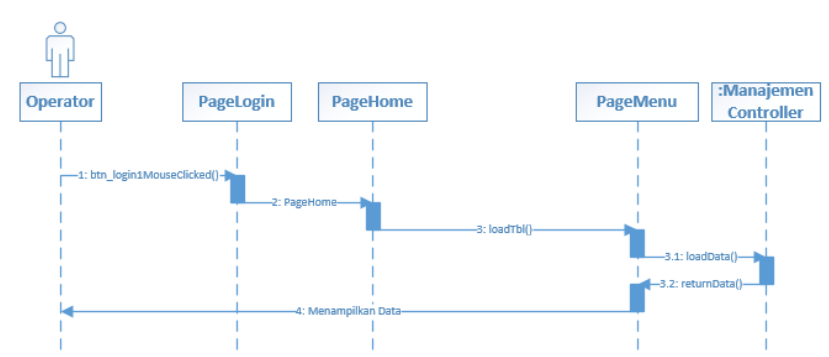

Gambar 4. Proses Lihat Data

\subsubsection{Proses Tambah Data}

Pada aplikasi ini user dapat memasukkan data melalui fitur tambah data yang ada pada tiap menu yang telah diakses. Gambar 5 menjelaskan proses tambah data yang dilakukan user dimana data yang telah dimasukkan pada form yang tersedia akan disimpan pada database.

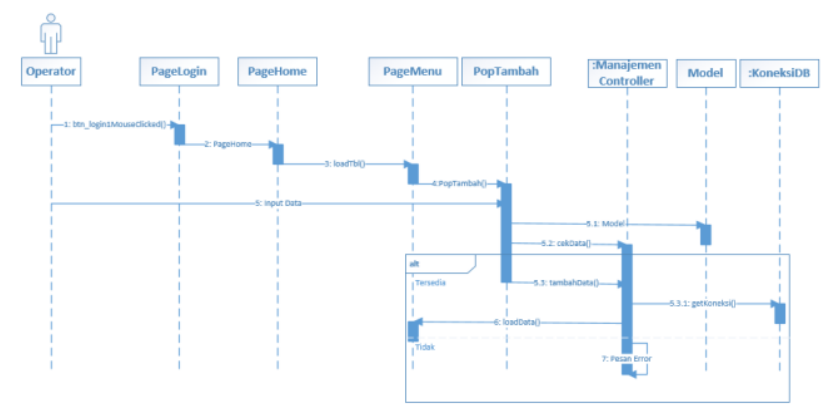

Gambar 5. Alur Menambahkan Data SIKASEP

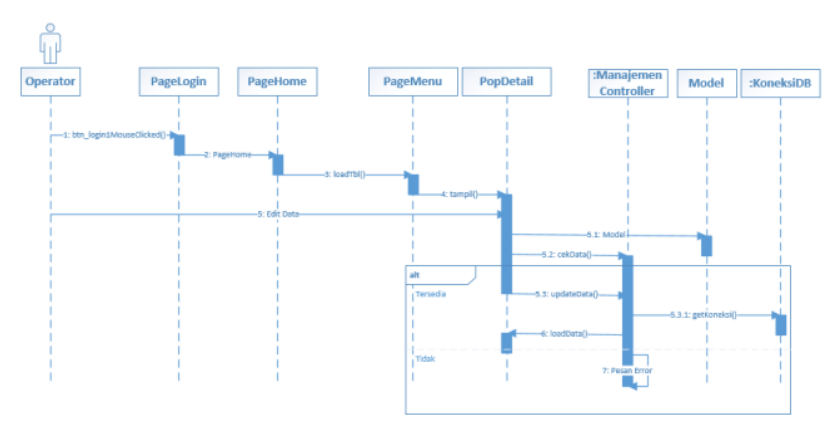

Gambar 6. Alur Mengubah Data SIKASEP

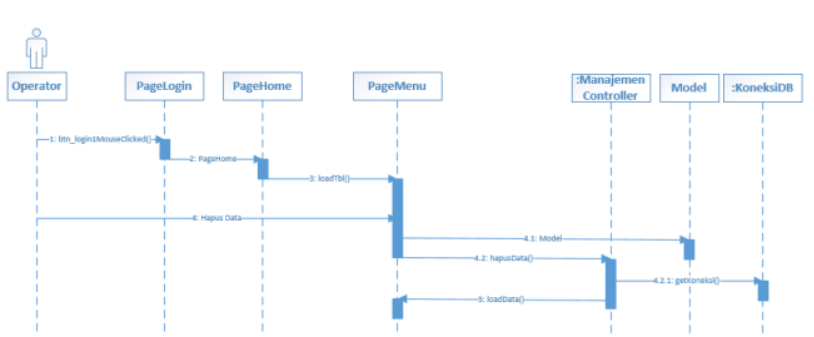

Gambar 7. Proses Hapus Data SIKASEP

\subsubsection{Proses Edit Data}

Pada aplikasi ini user dapat mengubah data yang salah melalui fitur edit data yang ada pada tiap menu yang telah diakses dan user melihat detail data. Gambar 6 menjelaskan proses edit data yang dilakukan user dimana sebelum data diubah data yang telah disimpan sebelumnya akan ditampilkan pada form yang disediakan baru kemudian user dapat mengubah data mana yang ingin dirubah. Setelah itu dilakukan pengecekan apakah data yang diubah tersebut tersedia atau tidak. Jika tersedia maka akan disimpan pada database.

\subsubsection{Proses Hapus Data}

Pada aplikasi ini user dapat menghapus data melalui fitur hapus data yang ada pada tiap menu yang telah 
diakses. Gambar 7 menjelaskan proses hapus data yang dilakukan user dimana data yang akan dihapus harus dipilih terlebih dahulu.

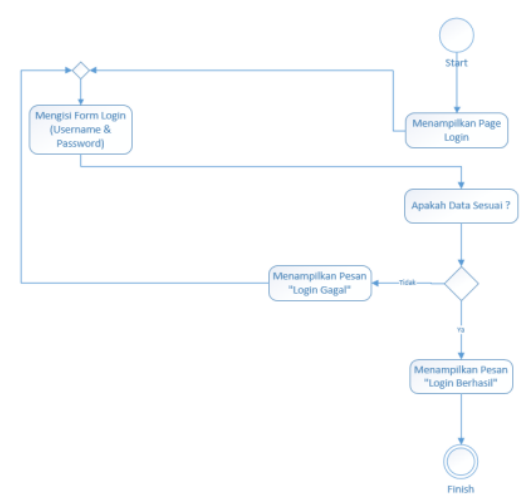

Gambar 8. Activity Diagram (Proses Login)

\subsubsection{Activity Diagram}

Berikut merupakan activity diagram dari Sistem Kendali Arsip Kepegawaian (SIKASEP) pada Balai Sosial Bina Remaja "Karya Mandiri". Diagram ini ditunjukkan dari Gambar 8 hingga Gambar 12.

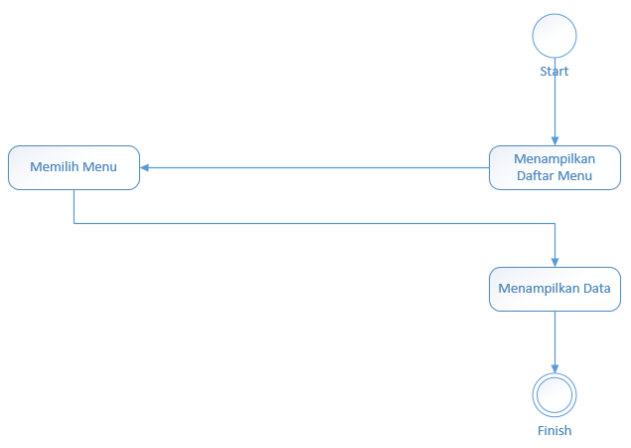

Gambar 9. Diagram Activity (Lihat)

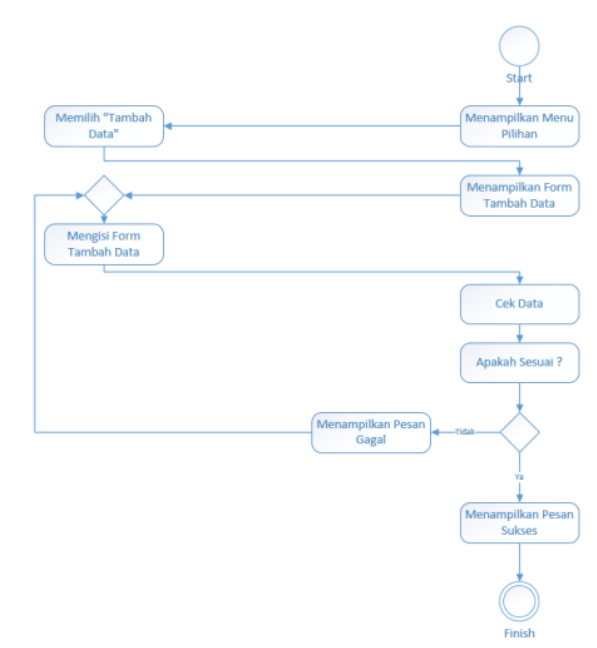

Gambar 10. Diagram Activity (Tambah)

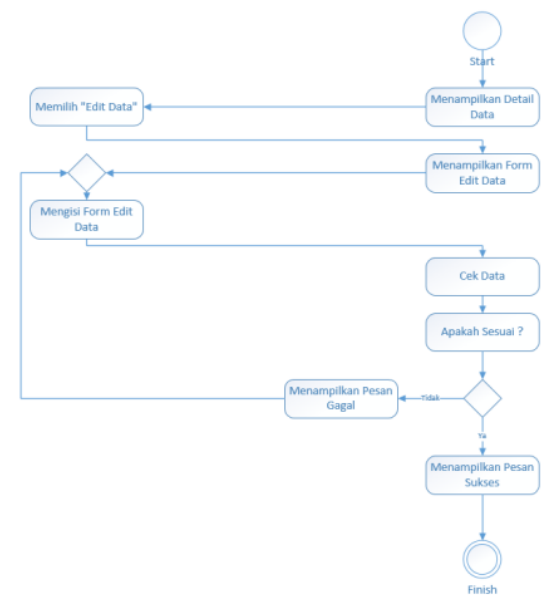

Gambar 11. Diagram Activity (Edit)

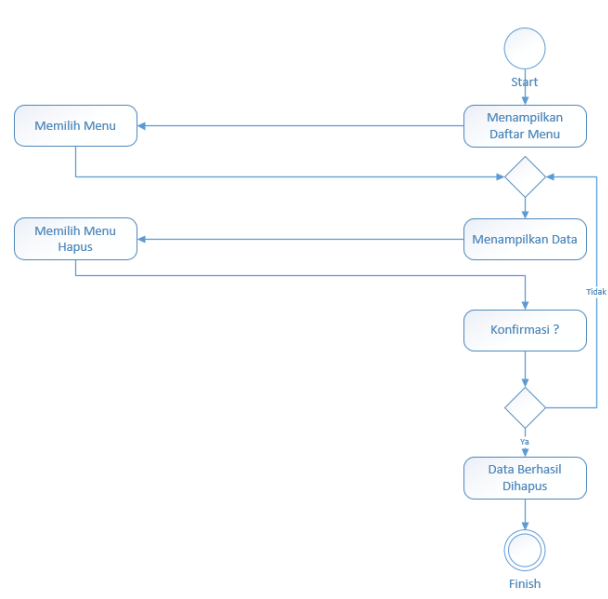

Gambar 12. Diagram Activity (Hapus)

\subsubsection{Entity Relationship Diagram (ERD)}

Pada Gambar 13 adalah ERD dari Kendali Arsip Kepegawaian (SIKASEP) pada Balai Sosial Bina Remaja "Karya Mandiri". ERD menjelaskan hubungan (relasi) antar entitas beserta atribut-atribut yang dimilikinya.

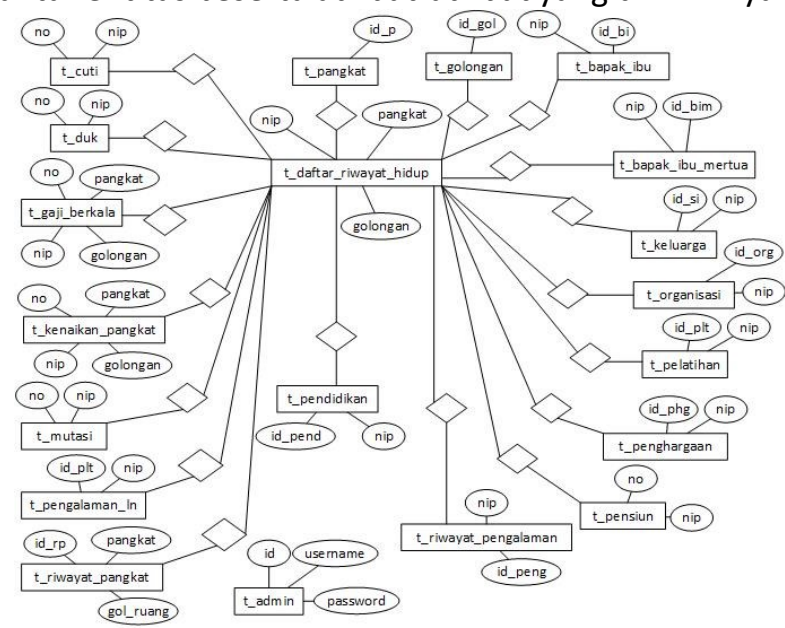

Gambar 13. Entity Relation Diagram (ERD) 


\subsubsection{Antarmuka (Interface)}

Adapun rancangan desain interface dari sistem informasi yang dibuat adalah sebagai berikut.

Gambar 14 adalah desain interface halaman Login yang merupakan halaman pertama pada sistem yang akan dijalankan. Terdapat dua field yang dapat diisikan user yaitu username dan password. Terdapat satu tombol login yang dapat digunakan user untuk masuk ke dalam sistem.

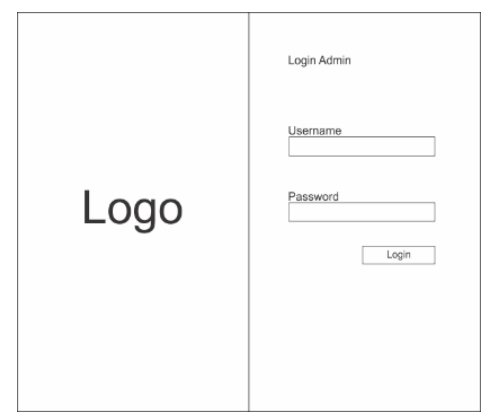

Gambar 14. Desain Interface Halaman Login

Gambar 15 adalah desain interface halaman home dimana ada fitur-fitur yang bisa di buka oleh user.

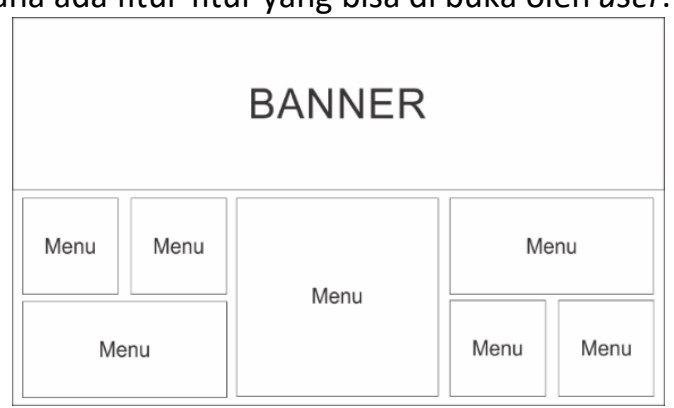

Gambar 15. Antarmuka Halaman Home

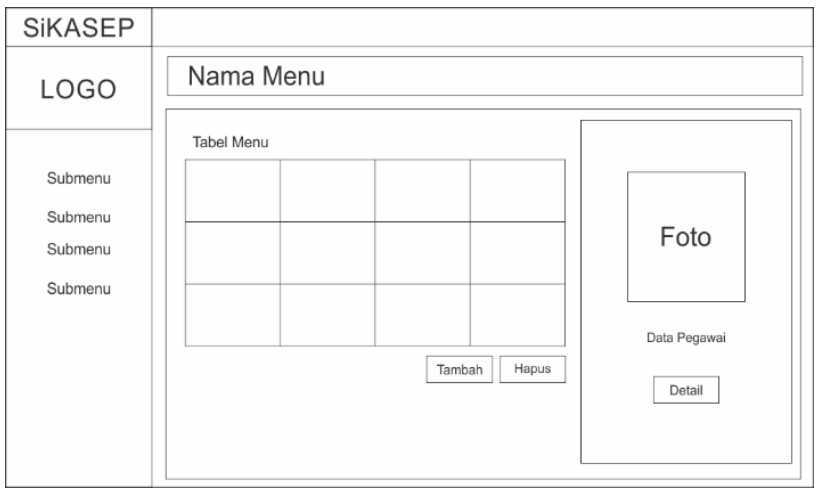

Gambar 16. Antarmuka Halaman Menu

Gambar 16 adalah desain interface halaman menu dimana halaman ini diakses setelah user memlih menu pada halaman home. Disini user dapat melihat data dari masing-masing menu serta terdapat juga tombol "tambah" untuk menambahkan data, "hapus" untuk menghapus data, dan "detail" untuk melihat data secara detail.

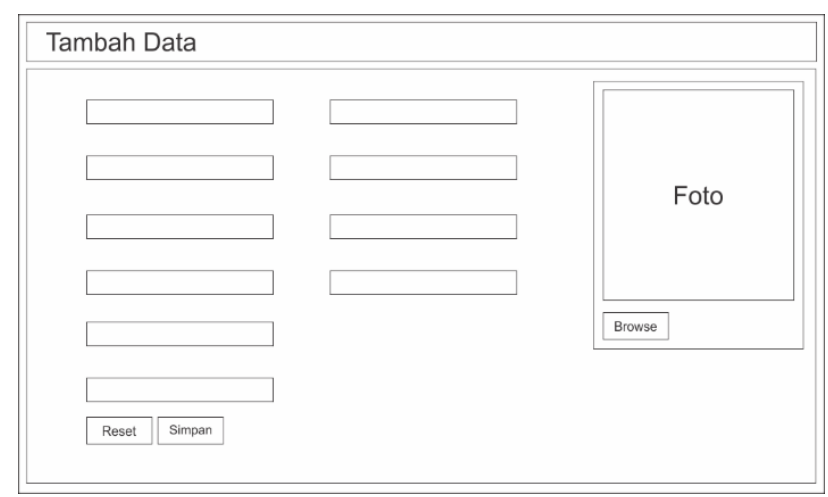

Gambar 17. Antarmuka Halaman Menu Tambah

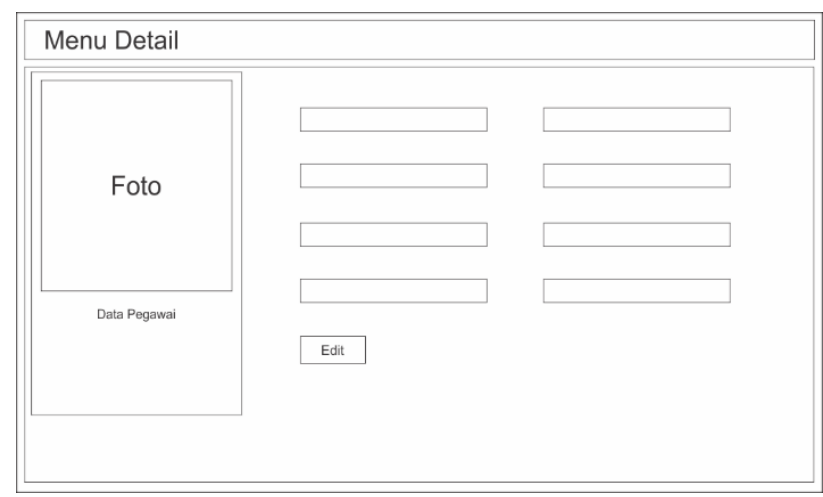

Gambar 18. Antarmuka Halaman Menu Detail

Gambar 17 adalah desain interface halaman menu tambah dimana halaman ini digunakan user untuk menambahkan data pada field-field yang tersedia. Terdapat tombol "reset" untuk mereset data yang sedang di isi dan fitur simpan untuk merekam data yang sudah di isi.

Gambar 18 adalah desain interface halaman menu detail dimana halaman ini digunakan untuk menampilkan data yang dipilih user secara detail. Terdapat tombol "edit" untuk mengubah data.

\begin{tabular}{|lllll}
$\#$ & Name & Type & Collation Attributes & Null Default \\
\hline 1 & id & int(11) & No None \\
\hline 2 & nama_depan & varchar(35) & No None \\
\hline 3 & nama_belakang & $\operatorname{varchar}(35)$ & No & None \\
4 & username & varchar(15) & No None \\
\hline 5 & password & varchar(35) & No None
\end{tabular}

Gambar 19. Struktur Tabel t_admin 


\begin{tabular}{|c|c|c|c|c|c|}
\hline$\#$ & Name & Type & Collation Attributes & Null & Default \\
\hline 1 & nip & $\operatorname{varch} a r(20)$ & & No & None \\
\hline 2 & nama & varchar $(50)$ & & No & None \\
\hline 3 & pangkat & varchar(15) & & No & None \\
\hline 4 & golongan & varchar $\{10\}$ & & No & None \\
\hline 5 & tempat_lahir & $\operatorname{varchar}(20)$ & & No & None \\
\hline 6 & tanggal_lahir & date & & No & None \\
\hline 7 & jenis_kelamin & varchar $(10)$ & & No & None \\
\hline 8 & agama & varchar $(20)$ & & No & None \\
\hline 8 & status_kawin & varchar $(50)$ & & Yes & MUL \\
\hline 10 & jalan_rumah & text & & No & None \\
\hline 11 & kelurahan & varchar $(20)$ & & No & None \\
\hline 12 & kecamatan & varchar $\{20\}$ & & No & None \\
\hline 13 & kab_kota & varchar $(20)$ & & No & None \\
\hline 14 & propinsi & varchar $(25)$ & & No & None \\
\hline 15 & tinggi_badan & $\operatorname{int}(5)$ & & No & None \\
\hline 16 & berat_badan & $\operatorname{int}(5)$ & & No & None \\
\hline 17 & rambut & varchar(15) & & Yes & MUL \\
\hline 18 & bentuk_muka & varchar $\{20\}$ & & Yes & MULL \\
\hline 18 & warna_kulit & $\operatorname{varch} \operatorname{ar}(20)$ & & Yes & MULL \\
\hline 20 & ciri_khas & varchar $\{30\}$ & & Yes & MUL \\
\hline 21 & cacat_tubuh & varchar $(30)$ & & Yes & MULL \\
\hline 22 & hoby & varchar $\{30\}$ & & Yes & MLL \\
\hline 23 & fo & $v$ & & Jo & la \\
\hline
\end{tabular}

Gambar 20. Struktur Tabel t_daftar_riwayat_hidup

\section{Hasil dan Pembahasan}

Berikut penjelasan hasil dan pembahasan dari sistem ini.

\subsection{Implementasi Database}

Berikut adalah screenshot database MySQL hasil implementasi desain database dari Sistem Kendali Arsip Kepegawaian (SIKASEP) pada Balai Sosial Bina Remaja "Karya Mandiri" dengan nama database adalah "db_sikasep".

Implementasi tabel menyesuaikan dengan tabel dari ERD. Bentuk tabelnya ditunjukkan di Gambar 19 dan Gambar 20.

\subsection{Implementasi Sistem}

Berikut adalah beberapa tampilan antar muka program hasil implementasi desain dari Sistem Kendali Arsip Kepegawaian (SIKASEP) pada Balai Sosial Bina Remaja "Karya Mandiri". Implementasi desain interface menyesuaikan dengan desain interface yang telah dibahas pada sub-bab sebelumnya:

\subsubsection{Halaman Login}

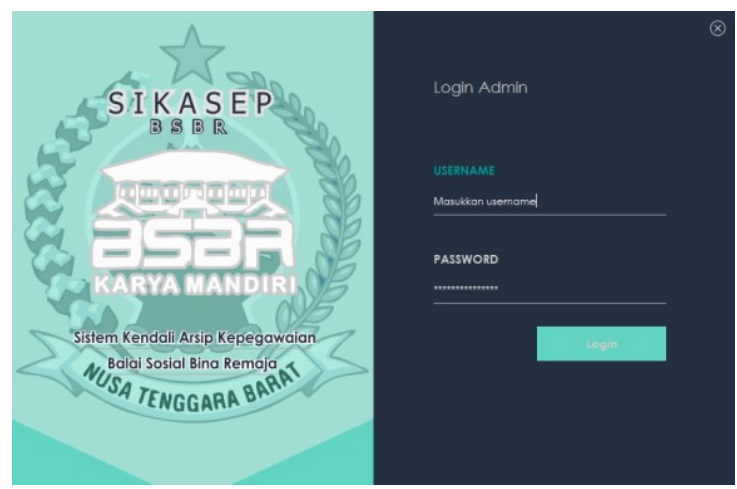

Gambar 21. Halaman Login

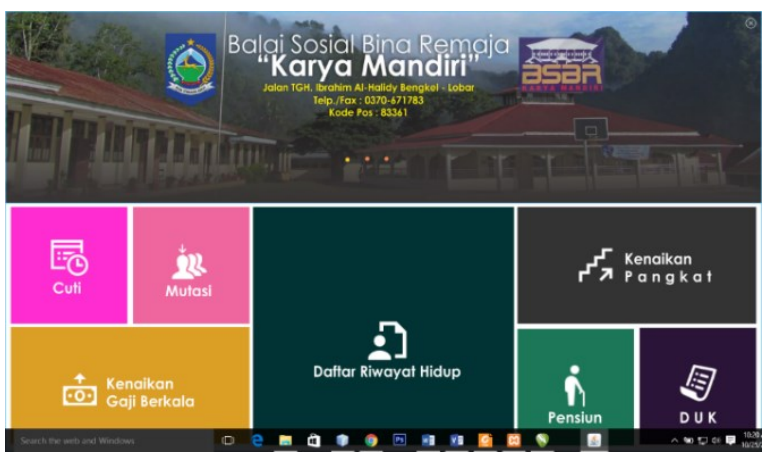

Gambar 22. Halaman Utama (Home)

Gambar 21 adalah halaman Login yang merupakan halaman pertama pada sistem yang akan dijalankan. Setelah melakukan login maka user akan diarahkan ke halaman utama (home) seperti pada Gambar 23.

\subsubsection{Halaman Utama (Home)}

Gambar 22 adalah halaman utama (home) yang terdiri dari pilihan fitur-fitur. Jika user menekan satu menu, maka tampilan berikutnya seperti pada Gambar 23.

\subsubsection{Halaman Menu}

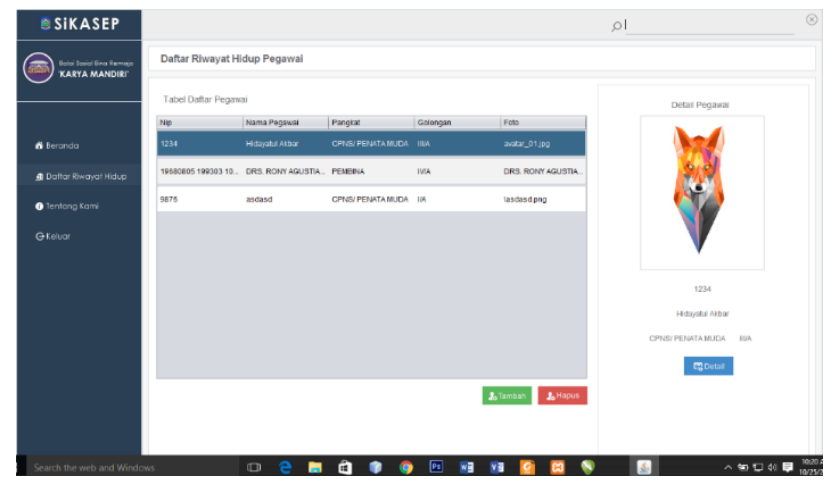

Gambar 23. Halaman Menu 
Gambar 23 adalah halaman menu dari menu yang dipilih oleh user pada halam utama (home). Pada halaman ini akan ditampilkan daftar data berdasarkan menu yang ada yang jika dipilih salah satunya maka akan muncul detail data dari pegawai yang memiliki data tersebut pada sisi sebelah kanan layar. Kemudian terdapat tiga buah tombol yaitu tombol "tambah", "hapus", dan "detail". Jika user memilih tombol "tambah" makan user akan diarahkan menuju halaman menu tambah seperti pada Gambar 24. Jika user memilih tombol "detail" maka akan diarahkan ke halaman menu detail seperti pada Gambar 25.

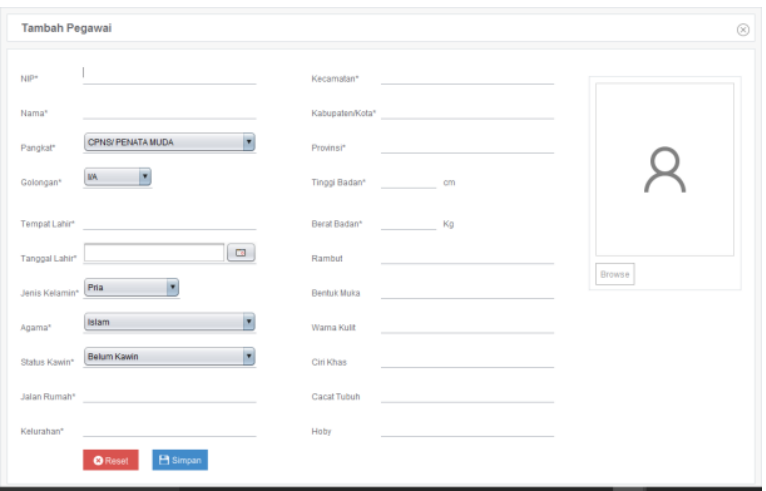

Gambar 24. Halaman Menu Tambah

\subsubsection{Halaman Menu Tambah}

Gambar 24 adalah halaman menu tambah yang akan digunakan user untuk memasukkan data. Terdapat field-field yang digunakan oleh user untuk memasukkan data, serta terdapat juga tombol "reset" dan "simpan". Jika user memilih tombol "reset" maka data yang telah diisikan pada field akan dihapus oleh sistem. Jika user memilih tombol "simpan" maka data yang dimasukkan akan tersimpan di database.

\subsubsection{Halaman Menu Detail}

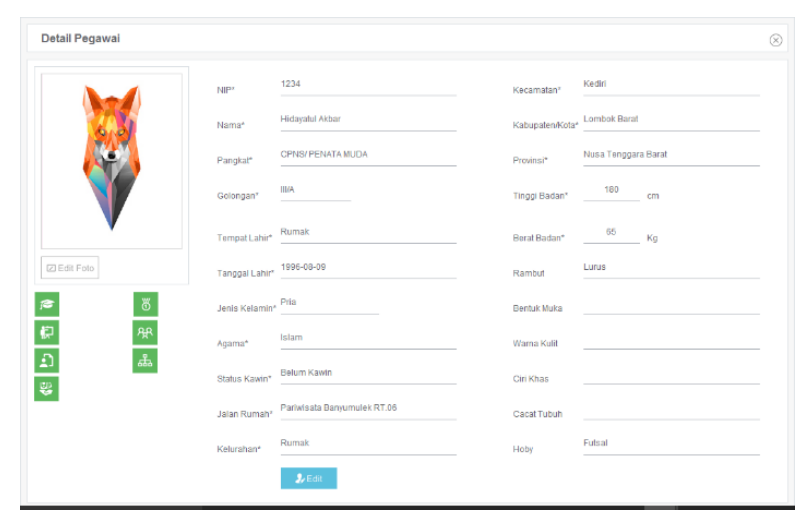

Gambar 25. Halaman Menu Detail
Gambar 25 adalah halaman menu detail yang diakses ketika user memilih tombol "detail" pada halaman menu sebelumnuya. Pada halaman ini akan ditampilkan keseluruhan data yang telah dipilih dalam bentuk field-field. Kemudian terdapat tombol "edit" yang digunakan untuk merubah data jika terdapat data yang salah yang dapat dilihat seperti pada Gambar 26.

\subsubsection{Halaman Edit}

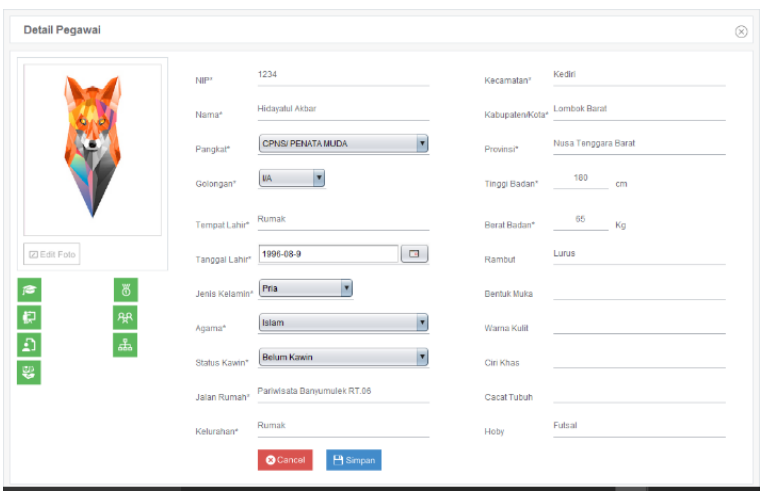

Gambar 26. Halaman Menu Edit

Gambar 26 adalah halaman menu edit yang digunakan oleh user untuk merubah data. Terdapat beberapa field dimana dalam tiap field terdapat data yang sudah ada sebelumnya untuk dirubah oleh user. Terdapat tombol "cancel" untuk membatalkan proses edit dan akan kembali ke halaman menu detail, serta tombol "simpan" untuk menyimpan data yang dirubah pada database.

\subsection{Pengujian Sistem}

Tahap ini dilakukan untuk melihat kinerja dari sistem yang telah diusulkan.

\subsubsection{Hasil Pengujian Black Box}

Black box dilakukan untuk menguji semua fungsi di dalam sistem untuk menentukan sudah berjalan sesuai harapan atau tidak.

Berdasarkan pengujian black box yang telah dilakukan terhadap seluruh fungsi yang ada di dalam system. Semua fungsi yang ada pada sistem ini telah di uji dengan berbagai kondisi dan data masukan yang berbeda-beda, dan semua fungsi yang telah ada pada aplikasi ini sudah berjalan dengan baik.

\subsubsection{Hasil Pengujian Mean Opinion Score (MOS)}

Metode MOS adalah penilaian kualitatif dari hasil kuisioner. Berdasaran hasil pengujian kuisioner yang dilakukan pada Kepala Balai Sosial Bina Remaja "Karya Mandiri", Kasubag Tata Usaha, Kelompok Jabatan Fungsional, Seksi Rehabilitasi dan Pemberdayaan 
Sosial, dan Seksi Penyantuan, beserta staf pegawainya, maka dapat dihitung total keseluruhan dari pernyataan responden sebanyak 30 orang.

Berikut merupakan grafik persentase jawaban rata-rata pengujian yang dilakukan melalui kuesioner terhadap aplikasi yang telah dibuat. Grafik ini dapat dilihat pada Gambar 27.

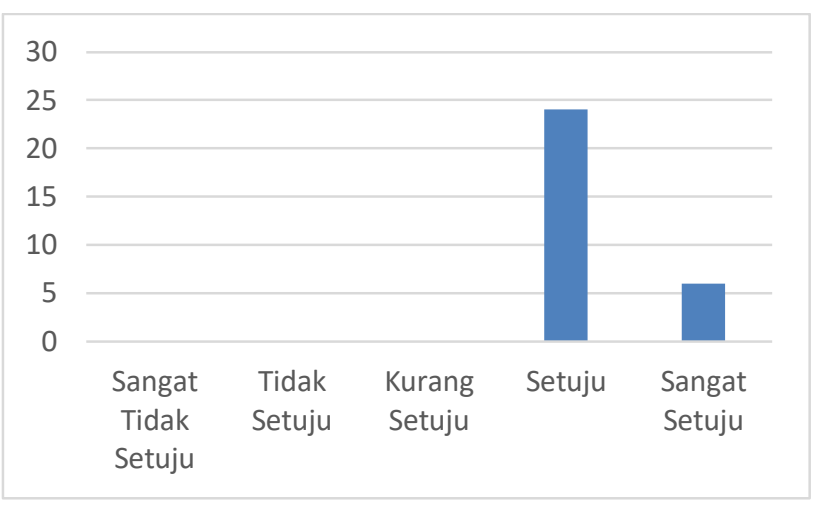

Gambar 27. Persentase jawaban kuisioner

Gambar 27 menunjukkan bahwa persentase jawaban respon sangat tidak setuju, tidak setuju, dan kurang setuju yaitu $0 \%$, sedangakan nilai untuk setuju sebanyak 24 responden (80\%) dan sangat setuju sebanyak 6 responden (20\%), sehingga dapat disimpulkan bahwa dari responden setuju dengan sistem ini.

\section{KESIMPULAN DAN SARAN}

Berikut kesimpulan dan sarannya dari penelitian ini.

\subsection{Kesimpulan}

Kesimpulan dari penelitian ini yaitu:

a. Untuk membangun sistem informasi ini maka harus dilakukan analisa sesuai dengan kebutuhan pengguna. Analisa juga dilakukan terhadap tiaptiap proses yang ada agar sistem dapat berjalan sesuai dengan prosedur yang telah ada.

b. Desain sistem pada sistem informasi ini dibuat dengan memperhatikan proses yang ada pada Balai Sosial Bina Remaja "Karya Mandiri" itu sendiri. Tools yang digunakan yaitu Netbeans sebagai penyedia utilitas yang diperlukan dalam pengembangan sistem, dan XAMPP berguna sebagai penyedia keperluan simulasi database sistem.

c. Sistem Kendali Arsip Kepegawaian (SIKASEP) dapat digunakan untuk membantu operator dalam menyimpan data dan mengolah data arsip pegawai dengan lebih mudah, efektif dan efisien. d. Hasil kuesioner dari aplikasi ini menunjukkan bahwa sebanyak 24 responden menyatakan setuju sebesar $80 \%$ dan sebanyak 6 responden menyatakan sangat setuju sebesar $20 \%$ untuk penggunaan aplikasi ini.

\subsection{Saran}

Saran dari penelitian ini yaitu:

a. Sistem Kendali Arsip Kepegawaian (SIKASEP) ini diharapkan dapat diterapkan untuk divisi lainnya sehingga data arsip yang ada dapat dikelola dengan baik.

b. Dalam pengembangan selanjutnya, Sistem Kendali Arsip Kepegawaian (SIKASEP) diharapkan dapat diintegrasikan dengan sistem lain yang dapat saling berhubungan sehingga akan meningkatkan fungsionalitas sistem.

\section{DAFTAR PUSTAKA}

[1] E. A. K. Lestari, S. E. Anjarwani dan N. Agitha, "Rancang Bangun Sistem Informasi Surat Perintah Perjalanan Dinas pada Sekretariat Daerah Provinsi Berbasis Web", J-COSINE, vol. 2, no. 1, hal. 29, Juni 2018.

[2] Mulyadi, "Efektivitas Sistem Kearsipan Dinamis (Sikd) Sebagai Sarana Temu Kembali Arsip Di Dinas Arsip, Perpustakaan Dan Dokumentasi (Arpusdok) Kota Palembang", JIPI (Jurnal IImu Perpustakaan dan Informasi), Vol. 3, No. 1, 2018.

[3] N. A. Hidayah, N. Kumaladewi dan T. T. A. Ristian, "SI Kepegawaian Berbasis Web pada Balai Besar Teknologi Energi (B2TE) Balai Pengkajian Penerapan Teknologi (BPPT) Serpong", Seminar Nasional Pengaplikasian Telematika SINAPTIKA, hal. 398, 2010.

[4] O. D. Prasetya, "Sistem Informasi Pengarsipan Data Surat Masuk Dan Surat Keluar Pada Polrestabes Semarang", Prodi SI Fak. Ilmu Komputer Universitas Dian Nuswantoro Semarang, 2013.

[5] Sumiati, S. E. Anjarwani dan M. A. Albar, "Rancang Bangun Sistem Informasi Pengelolaan Surat dan Kearsipan pada Sekretariat Daerah Provinsi NTB Berbasis Web", J-COSINE, vol. 2, no. 1, hal. 7, Juni 2018.

[6] Triyono, F. Samopa dan U. Burhan, "Pembuatan SI Penatausahaan Surat dan Arsip Berbasis Web Studi Kasus Kantor Pelayanan Perbendaharaan Negara Bengkulu", JURNAL TEKNIK POMITS, vol. 2, no. 2, hal. 346, 2013.

[7] M. Reza Fachlevi, R. Fenny Syafariani "Perancangan Sistem Informasi Kepegawaian Berbasis Website di Bagian Kepegawaian SDN Binakarya 1 Kabupaten Garut", Jurnal SIMETRIS, Vol. 8, No. 2, hal.553, 2 November 2017. 
[8] D. Abdullah, "Perancangan SI Pengolahan Data Pegawai Berbasis Web di Setdakab Aceh Utara", TECHSI Jurnal Penelitian Teknik Informatika, Vol. 4, No. 1, hal. 35, 2014.

[9] H. Nisa, S. Esabella, Rodianto, "Sistem Informasi Kepegawaian Berbasis Web Pada Unit Pelaksana Teknis (UPT) Puskesmas Kecamatan Unter Iwes", Jurnal Tambora, Vol. 2, No. 3, hal. 1, 3 Desember 2017.
[10] S. Nurbaity, "Pengembangan SI Kepegawaian (SIMPEG) Berbasis Web (Studi Kasus: Subbag Administrasi Kepegawaian Pusat UIN Syarif Hidayatullah Jakarta)", Program Studi Teknik Informatika Fakultas Sains dan Teknologi Universitas Islam Negeri Syarif Hidayatullah Jakarta, 2010. 